quality in regard to $p \mathrm{H}$ value than ordinary distilled water. The inner condenser is water-cooled, and the flow is adjusted so that the distilled water issues nearly at the boiling point.

\section{Processing Quartz}

THE production of a small thin quartz plate from a large crystal weighing several pounds involves a long succession of operations, including repeated cutting, surfacing and checking. Each step requires some form of grinding or lapping, and with the extremely high precisions required and material so hard as quartz, these processes are slow and exacting, although multiple processing reduces the het time per erystal considerably. Until crystals began to be used extensively in electrical work, the grinding of hard brittle substances was limited chiefly to jewels, and the techniques and materials employed were not very well suited to a large-scale processing of quartz. As a result, a considerable amount of research and development was carried out in the Bell Laboratories to discover the most satisfactory methods and to design the most useful machines. An article by W. L. Bond (Bell Lab. Rec., 22, No. 8 ; April 1944) describes the various lapping and grinding processes employed.

\section{Accidental Poisoning in the United States}

IN the United States, about 1,200 deaths occur each year from accidental poisoning. Analysis of the 355 cases occurring among policy-holders of the Metropolitan Life Insurance Company during 194043 (Statist. Bull., 25, No. 2 ; 1944) reveals the following. More than a quarter of the victims were pre-school children, and among these the commonest poison was strychnine ( 20 cases), taken in the form of sugar-coated strychnine pills intended for adults, followed closely by oil of wintergreen (17 cases), taken by drinking the pleasant smelling liquid intended for external application. Among the adults the list was headed by overdose of sleeping drugs (72 cases); 49 took poison (commonest were lysol, sodium fluoride) in mistake for medicine ; 41 drank methyl alcohol believing it to be a satisfactory substitute for ethyl, and 18 drank poison in mistake for an alcoholic beverage.

\section{Anti-plague Campaign in Chimborazo}

According to Dr. C. S. Vera, of Riobamba (Bol. Of. San. Panamer., 22, 875 ; 1943), a successful antiplague campaign was carried out in the province of Chimborazo, Ecuador, during August 1, 1942July 21,1943 . The central office set up in Riobamba directed the activities of the groups organized in each section of the province. 'Cynogas' and flame-throwers were used in destroying rat nests, and a paste of arsenic and phosphorus was used in rat burrows. During the year 43,876 .rats were trapped (rattus 13,730, alexandrius 10,322 and musculus 19,815), and almost complete extermination was accomplished in some areas. The spleens of 23,629 rats were examined, but only one (rattus) was positive. The incidence of plague in Chimborazo was as follows : 1939,82 cases; 1940,40 cases; 1941,30 cases ; 1942, 1 case, and in the first six months of 1943 nil.

\section{Swedish Town Population}

According to recent statistics in the AngloSwedish Review of April, the population of the Swedish capital rose during 1943 by more than 21,000, which is the largest annual increase ever recorded, to 636,000. Greater Stockholm including the suburban districts of the capital now has 800,000 inhabitants, or one eighth of Sweden's entire population. The same increasing tendency is registered for most Swedish towns, 111 out of the country's 123 towns showing rising population figures; Sweden's second town, Gothenburg, has 290,000 inhabitants and the third largest, Malmö, 163,000.

\section{Summer School in X-Ray Crystallography}

A Summer School in X-ray crystallography applied to industrial problems is being held in the University of Cambridge in September along the lines of the school organized last year which proved to be very successful. It is being arranged again by the Departments of Physics and of Mineralogy and Petrology in co-operation with the Board of Extramural Studies. In the course, which has been modified as a result of the experience of last year, emphasis will be placed on the interpretation of practical work and on the application of different techniques to various problems. It is particularly designed for scientific workers and technicians who are using the methods of X-ray diffraction in industry and who have had no systematic training in the subject. The Summer School will extend from September 4 to September 16. In view of the present shortage of staff, apparatus and materials, it will be possible to accept only a limited number of people, and application to attend must be made before July 24. Further information can be obtained from the Secretary of the Board of Extra-mural Studies, Stuart House, Mill Lane, Cambridge.

\section{Announcements}

Mr. G. D. H. Cole, University reader in economics, Oxford, and director of the Nuffield College Social Reconstruction Survey, has been appointed Chichele professor of social and political theory at Oxford as from October 1 .

THE honorary degree of LL.D. has been conferred by the University of St. Andrews on Sir Robert Robinson, Wayneflete professor of chemistry in the University of Oxford.

THE honorary degree of LL.D. has been conferred by the University of Aberdeen on Prof. Alexander Findlay, professor of chemistry in the University during 1919-43 ; Prof. V. M. Goldschmidt, professor of mineralogy and geology, University of Oslo ; Sir William Wright Smith, regius professor of botany in the University of Edinburgh.

The degree of D.Sc. has been conferred on Dr. G. A. Cowie, for a thesis on "Study of the Effects of Manures and Rainfall on Yields of Crops grown in Rotation"; J. S. Farquharson for a thesis on "(1) Haboobs and Instability in the Sudan, (2) The Diumal Variation of Wind over Tropical Africa"; Dr. H. W. Kosterlitz, for a thesis on "Some Observations on the Conversion of Galactose to Glucose in Mammalian Liver and in Yeast". The degree of Ph.D. has been conferred on Charity Waymouth, for a thesis on "An Investigation of Various Substances of Biochemical Importance for Tissue Growth".

Messrs. H. K. Lewis AND Co., Ltd., 136 Gower Street, London, W.C.1, have been appointed sole distributing agents for the reproductions of German technical books issued by Mr. J. W. Edwards and Edwards Brothers Inc., of Ann Arbor, Michigan. A catalogue of the titles is in preparation. A copy will be sent on request. 